\title{
Doctoral Students' Sense of Relational Agency in Their Scholarly Communities
}

Kirsi Pyhältö (Corresponding author)

The Centre for Research and Development in Higher Education

University of Helsinki

PO Box 9 (Siltavuorenpenger 5 A) 00014 University of Helsinki, Finland

Tel: 358-50-415-0132Ｅ-mail: Kirsi.Pyhalto@helsinki.fi

Jenni Keskinen

Department of Teacher Education

University of Helsinki

PO Box 9 (Siltavuorenpenger 7) 00014 University of Helsinki, Finland

Tel: 358-318-2227Ｅ-mail: Jenni.Keskinen@helsinki.fi

Received: August 6, 2012

doi:10.5430/ijhe.v1n2p136
Accepted: August 27, $2012 \quad$ Online Published: August 29, 2012

URL: http://dx.doi.org/10.5430/ijhe.v1n2p136

\begin{abstract}
The literature emphasizes the importance of integrating doctoral students into scholarly communities and practices at the very beginning of their studies. Although the importance of student participation in a scholarly community has been recognized empirical evidence concerning the quality of participation that promotes such engagement is scarce. This study focuses on exploring doctoral students' sense of relational agency in terms of their scholarly communities and how this is related to study persistence and experienced socio-psychological well-being. Altogether 669 doctoral candidates from three faculties (humanities, medicine, and behavioural sciences) from a large research-intensive Finnish University completed a doctoral student survey. The results showed that a minority of the students perceived themselves as active relational agents in terms of their scholarly communities. However, students who perceived themselves as active relational agents experienced less lack of interest in their studies, less negative emotions, and less often considered abandoning their studies than students who perceived themselves as passive objects in their communities.
\end{abstract}

Keywords: Relational agency, Doctoral student, Doctoral education, Scholarly community

\section{Introduction}

Doctoral students' learning can be considered the key element not only of the students' professional development but also in creating new ideas and scientific knowledge. The scholarly community provides the primary context for doctoral studies. Hence, doctoral student learning is highly embedded in the scholarly community's practices. It is known that student involvement with the scholarly community contributes, for example, to the doctoral experience (e.g. Gardner, 2008, 2010; Pyhältö, Stubb \& Lonka, 2009) as well as educational outcomes such as degree completion, time-to-candidacy, employment after the completion and competencies developed while studying (Lovitts, 2005; Wulff \& Nerad, 2006; Sainio, 2010; Stubb, Pyhältö \& Lonka, 2011). Good practices reported in the literature emphasize the importance of integrating students into disciplinary communities and practices at the very beginning of their studies (e.g. Dysthe, 2006; Walker, 2008). For example, Golde, Bueschell, Jones, and Walker (2009) have recently proposed that the more opportunities there are to interact, the more likely students are to share ideas, gain input and learn. Although the importance of student participation in the scholarly community has been recognized (Golde 2000; 2005; Lovitts, 2001; Pyhältö, Stubb \& Lonka, 2009), empirical evidence concerning the quality of participation that promotes doctoral student engagement is scarce, resulting in a gap in the literature. This study attempts to help fill this gap by exploring doctoral students' sense of relational agency in terms of their scholarly communities, and how this is related to study persistence and experienced socio-psychological well-being. 


\subsection{Doctoral students' relational agency in scholarly communities}

To become a researcher, engagement in the various practices of the scholarly community has been seen to be central (Delamont et al., 2000). A link has been shown to exist between the amount of faculty-student interaction and students' involvement in research projects (Weidman \& Stein, 2003), productivity during studies (Nettles \& Millet, 2006) and higher rates of degree completion (Cook \& Swanson, 1978). There is also evidence of collaborative and activating learning environments promoting meaningful learning in doctoral education. Haworth and Bair (2000), for example, showed that individualized mentoring and engagement in authentic problem solving during research-based discovery activities was related to meaningful learning experiences reported by doctoral students. Moreover, Austin (2002) reported that doctoral students identified support from doctoral programme communities, particularly the faculty, as an essential ingredient of the doctoral experience. On the other hand, evidence shows that internal locus of control and self-direction are essential in making the most of doctoral education (Anderson \& Anderson, 2011). These findings indicate that active and reciprocal participation is likely to play a central role in meaningful doctoral student learning in terms of both creating new knowledge and developing as a scholar.

We use the term relational agency (Edwards, 2005; 2011; Edwards, Lunt \& Stamou, 2010) to refer to the capacity of doctoral students to work with others in order to better respond to complex research problems. This includes working with others to expand the "object of activity", in this case doctoral research, by recognizing the motives and resources of others, interpreting them, and aligning one's own responses to these interpretations with the responses of others involved while expanding knowledge in terms of the doctoral project. However, agency is not only about adaptation (Hopwood, 2010). According to Neumann, Terosky and Schell (2006) agency refers to faculty member's capacity to construct the context of their own learning. This means that doctoral students are not influenced only by the academia but can, at least to some extent, choose their primary arenas in which to participate. They can, for instance ignore, adapt to, or adopt the practices, or even leave the community entirely. This indicates that doctoral student's relational agency can also involve well justified opposition, making initiatives as well as the transformation of dominant power relations within the community (Elder, 1997). Therefore by adopting different strategies, the students can actively modify their environment, and hence their opportunities to engage in the scholarly community in question (Virtanen \& Pyhältö, 2012). Further, the way in which doctoral students engage with their scholarly community, i.e. their relational agency, contributes to what they learn during their doctoral studies.

Because sense of agency, while internal, is always constructed in a physical, social, and cultural context the work environment can either promote or reduce faculty members' senses of agency $\left(\mathrm{O}^{\prime}\right.$ Meara, Terosky \& Neumann, 2008). Further, doctoral students as well as other faculty members may feel that they have different abilities to exercise their agency based variety of personal, social and organizational resources and demands at hand ( $\mathrm{O}^{\prime}$ Meara \& Campbell, 2011). Therefore, an important aspect of developing relational agency is having an opportunity to participate and contribute (Greeno, 2006; Lipponen \& Kumpulainen, 2011; Pyhältö, Pietarinen \& Soini, 2010) to the interactions of the scholarly community. This requires creating arenas in which doctoral students are seen and treated as accountable authors. However, the students' active and responsive collaboration with the academic community that makes it possible to expand understanding and create new knowledge cannot be taken for granted.

One reason why becoming an accountable author in a scholarly community is challenging is that the community provides a dynamic, multilayered and nested learning environment for doctoral students (McAlpine \& Norton, 2006; Pyhältö, Toom, Stubb \& Lonka, 2012). The widest and simultaneously perhaps most abstract level of a scholarly community is the particular discipline, including the international community of researchers and the arenas that promote the development of new knowledge in the discipline, such as journals and conference meetings. As proposed by Pyhältö, Nummenmaa, Soini, Stubb, and Lonka (2012) the next level is typically the "organizational", consisting of the university and its faculties and departments. Closest to the doctoral students themselves are often the various communities of practices (Wenger, 1998), such as peers, seminars, research groups and research units. This complexity of scholarly communities is also reflected in how students have experienced their own communities. Pyhältö, Stubb and Lonka (2009), for instance, found that the definitions of "scholarly community" given by students varied, ranging from their own research group to the international research community.

Learning to become a scholar is highly embedded in scholarly communities' practices. These practices have their own cultural roots and reflect the values, norms and conceptions of a certain research domain while also being multior interdisciplinary in nature (Holley, 2010). As complex, interactive and dynamic learning environments, scholarly communities provide various arenas in which students may participate. Even within a single week doctoral students might work with peers, members of the professional community and undergraduate students. Hence during their studies students are exposed to various subcultures and roles in the complex community of practice (Wenger, 1998; 
Becher \& Trowler, 2001). Doctoral students' relational agency is situated in these practices. In other words, relational agency is not a fixed student characteristic; rather it is continually constructed and re-constructed through interaction (Pyhältö, Pietarinen \& Soini, 2012) within academia.

\subsection{Dynamics between the doctoral student and the scholarly community}

Doctoral students' opportunity to act as active relational agents in their academic communities is affected by the dynamics between the student and the scholarly community in question. The dynamic interplay therein can be explored in terms of person-environment fit. Fit refers to the congruence between individuals and their environments (Edwards, 2007; Kristof, 1996).

Previous studies on the doctoral experience indicate that perceived fit or misfit between doctoral students and their working environment influences the students' doctoral experience and completion of the process (e.g. Golde, 2005; Pyhältö, Tuomainen \& Stubb, 2012). Golde (2005), for instance, found that a misfit between doctoral students' goals/expectations and the norms and practices of their scholarly community affected their persistence. A perceived misfit between doctoral students and their working environment in terms of wrong department, problems with supervisors and uncertain career prospects have also been shown to contribute to student attrition (Golde, 1998). The quantity and quality of faculty-student interaction have been shown to have a significant impact on perceived fit, and consequently doctoral students' satisfaction and dissatisfaction with their studies (e.g. Gradner, 2007; Truong, 2010; Anderson, 2011). In their study on departmental characteristics and student attrition Ehrenberg, Jakubson, Groen, So \& Price (2007) showed that as students are enrolled longer in their doctoral programmes and advising improves, they have a greater ability to persist and graduate.

The literature indicates that typical of learning environments that promote doctoral students' engagement and empowerment in learning, i.e. relational agency, is having an opportunity to participate (Deci \& Ryan, 2002) and contribute (Eccles, 2008) to their scholarly community as accountable authors (Greeno, 2006; Pyhältö et al., 2011). Accordingly, at its best, this dynamic and complex interplay involves participating in various complementary practices that contribute to the gradual acquisition of expertise in one's domain.

It has been shown, however, that the scholarly community can also be problematic in terms of doctoral students' relational agency. Anderson, Luis \& Earle (1994), for instance, found that students having the best opportunities to learn research skills (i.e. those who collaborated most closely with faculty in research projects) were exposed to unethical behaviour the most. On the other hand, Pyhältö, Stubb, and Lonka (2009) found that how students experienced membership in their community varied considerably: close to a third of the PhD students in their study felt isolated from their academic community or felt the relationship between themselves and the community to be problematic. These findings indicate that experienced agency in terms of a scholarly community may vary, not only between scholarly communities but also between the working contexts within a single community.

\subsection{Doctoral students' well-being}

The faculty constitutes a multiple, interactive, complementary and sometimes even contradictory working environment for doctoral candidates. This means that the candidates may simultaneously experience engagement, joy and satisfaction when collaborating with other members of the scholarly community along with feelings of inadequacy brought about by problems in their research work. Hence, in positive cases the sense of relatedness and well-being generated in the scholarly community may function as a buffer, for example against feelings of inadequacy resulting from unsolved problems that the candidates face in their work (Stubb, Pyhältö \& Lonka, 2011).

However there is also evidence that scholarly communities do not always provide optimal opportunities for doctoral candidates to actively participate and engage in the practices of these communities. Recently, Stubb, Pyhältö, and Lonka (2011) more closely explored the relationship between experienced well-being and scholarly communities. They discovered a variation in students' experienced socio-psychological well-being in terms of scholarly community. The scholarly community was perceived by the doctoral candidates in question slightly more often as burdensome rather than inspirational and empowering. Moreover, feelings of empowerment were positively related to study engagement and negatively related to stress, exhaustion and anxiety.

Moreover, a significant number of doctoral students have been reported to experience ill-being during their studies. Several studies indicate that doctoral students suffer from stress and exhaustion, among other negative symptoms, during their studies (Appel \& Dahlgren, 2003; Bauer, Abric, Drozda-Senkowska, Lemaire, Lorenzi-Cioldi, Niedenthal, Santioso, Schadron, Steiner \& Yzerbyt, 2003; International Postgraduate Student Mirror, 2006; Authors, 2011; Toews, Lockyer, Dobson \& Brownell, 1993). Evidence exists of student satisfaction or dissatisfaction being related to the quantity and quality of student interaction with faculty (Barner \& Randall, 2011; Nettles \& Millett, 
2006). The quality faculty interaction has also reported to lead to a more positive postdoctoral experience (Scaffidi \& Bergman, 2011). In addition, drop-out rates among doctoral students are high, ranging from thirty to fifty percent, depending on the discipline and country (Gardner, 2008; Golde, 2000; McAlpine and Norton 2006). Similar findings have been reported in Finland; for instance, Stubb, Pyhältö and Lonka s (2011) found that 43\% of doctoral students had considered abandoning their studies.

These findings indicate that the quality of doctoral students' participation in their scholarly communities plays an important role in their study-related well-being, study engagement, and learning (Pyhältö et al, 2009; Stubb et al, 2011). Yet less in known about how doctoral students perceive their relational agency in scholarly communities and how this contributes to their well-being.

\section{The aim of the study}

The study explores doctoral students' sense of relational agency in their own scholarly community. The emphasis is on analysing the premises on which doctoral students view their participation in their particular community. Furthermore, the aim is to understand how students' sense of relational agency is related to experienced well-being in terms of negative emotions, to study persistence in terms of intentions to interrupt doctoral studies, and to the different disciplines. The aim is also to examine whether sense of relational agency was related to research group status, i.e. whether students reported working in research groups vs. working alone. The study is part of a larger national research project dealing with doctoral education in Finland (Pyhältö, Stubb \& Lonka, 2009).

\section{Method}

\subsection{Doctoral education in Humanities, Behavioural Sciences and Medicine in Finland}

In Finland, doctoral studies are closely intertwined with thesis research. No extensive separate course work is done before beginning a doctoral project; instead, seminars and course work (40-80 ECTS) are complementary to the thesis project and designed to support it. A doctoral thesis can be completed either in the form of a monograph or as a summary of articles (Finland's Council of State's regulation for university degrees 645/1997). In Humanities, most doctoral students $(83 \%)$ undertake a monograph dissertation. These students often participate in seminars, and supervision is based on supervisor-student dyads rather than intensive work done in research groups. In Medicine (96\%) and Behavioural Sciences (66\%), most candidates undertake article-based dissertations (Stubb, Pyhältö \& Lonka, 2011) usually consisting of 3-5 internationally refereed journal articles co-authored with the supervisor and other senior researchers, as well as a short summary including an introduction and discussion. The articles and summaries are generally written in English. The article-based dissertations are typically completed in a research group milieu (Stubb, Pyhältö \& Lonka, 2011). They often focus on solving collectively shared research problems related to a supervisor's research projects.

The average amount of time it takes to complete a degree in Medicine is 6 years and 10 months, Behavioural Sciences (Education) 6 years and 2 months, and Humanities 6 years and 8 months (Sainio, 2010). Doctoral education is publicly funded and costs the student nothing except living expenses. The most typical source of income among doctoral candidates in Medicine, Behavioural Sciences and Humanities is a personal grant (Pyhältö et al, 2011).

\subsection{Participants}

Altogether 668 doctoral candidates from three faculties of the University of Helsinki, Finland (humanities $n=348$, medicine $\mathrm{n}=163$, and behavioural sciences $\mathrm{n}=157$ ) completed a paper survey in 2006. The survey with pre-paid return envelope was sent to all doctoral students in the faculties of medicine, humanities and behavioral sciences. The response rate was $38.4 \%$. All respondents had MA degrees, and all were in various phases of their doctoral studies, although the majority (59\%) were in the final third of their thesis process (21\% were at the first third and $20 \%$ at the second third of their thesis process). Most of the respondents in each context were women, and the mean age was 39 years (Med: 35). Half of the students reported working full-time on their thesis, and the other half part-time. A majority (78\%) were working alone, only $13 \%$ in a research group and the rest $(9 \%)$ were working both alone and in a group. Altogether $43 \%$ of the students had considered interrupting their doctoral studies at some point. Due to the rather low response rate, we investigated our sample's representativeness by comparing it with all Finnish $\mathrm{PhD}$ students with respect to age, and with all University of Helsinki students with respect to gender, based on statistics from the University of Helsinki and Statistics Finland (Table 1).

\section{Insert Table 1 here}

The sample represented the population quite well in terms of gender distribution (see Table 1). In the absence of more detailed national statistics on Finnish doctoral students, we also analyzed the representativeness of our sample 
in relation to a larger national survey of Finnish doctoral students in all domains (Hiltunen and Pasanen, 2006; International Postgraduate Student Mirror 2006). The analysis showed that the working conditions of our sample group (whether the students worked alone or in a group; were they working part- or full-time on their theses) were quite similar to the larger national study. The only difference between our sample and the larger group was that most of the students in our survey were in the final third of their doctoral process, whereas the most in the national survey were in the early stages. This over-representation might be explained by that the fact that these students had more experience, and therefore they might have felt that they could participate in the study on the basis of this experience. Moreover, it is likely that those student who were actively conducting their doctoral studies were over presented in our data, because the survey was addressed to those student who were conducting their doctoral studies. The representativeness of the analysis is described in more detail in Stubb, Pyhältö and, Lonka (2011).

\subsection{Measurements and Data Collection}

The data were collected through a survey conducted in May 2006. The survey consisted of both Likert-type statements and open-ended questions. The themes of the open-ended questions concerned the students' ideas about the $\mathrm{PhD}$ process and its main influencing factors (e.g., problems and critical incidents), as well as their perceptions of themselves as part of the scholarly community and their perceptions of supervision. The structured items were designed to measure the students' perceptions of their learning environment, their stress, anxiety, and exhaustion as well as their ideas about academic writing and themselves as writers (see Table 2). In addition to these, there were background variables in the end portion of the survey (e.g., age, gender, working conditions). The survey was sent to all doctoral students in the faculties of medicine, humanities and behavioural sciences. The contact information of the students was collected from the student register database. Students who did not have Finnish as their mother tongue received the questionnaire in English. The survey was validated in a pilot study before conducting the survey in research contexts. Altogether $45 \mathrm{PhD}$ students majoring in natural sciences participated in the pilot in January 2006.

The present article focuses on one open-ended question ("How do you see your own role as a $\mathrm{PhD}$ student in your scholarly community?"), statements related to well-being, as well as students' intentions to interrupt studies. Altogether, 630 doctoral students responded to the open-ended question.

Insert Table2 here

\subsection{Analysis}

The answers were analysed using abductive qualitative content analysis (e.g. Coffey \& Atkinson, 1996). At first, all the answers in which doctoral students reflected their relationships and involvement in scholarly community were coded into same hermeneutic category. This resulted 460 descriptions, hence at this stage 150 answers that either provided too little information for further analysis or did not involved reflection about doctoral student relationship with their scholarly community were excluded from the analysis (e.g. I'm satisfied with my role). After this, the data were coded into two separate categories based on how students perceived their membership in their scholarly community:

Subject: Perceiving oneself as an active relational agent in terms of the scholarly community, including reporting a sense of belonging and empowerment in terms of their communities. The student emphasizes either being able to receive something personally significant from the community or being able to contribute to the community, or both.

Object: Perceiving oneself as a passive object in terms of the scholarly community, including having little or nothing to say about it. Within this category students also described themselves as being members of the community in terms of the external value (for instance funding) that their work meant for the community, or they did not experience being part of the community in any meaningful way.

Using the dichotomous categories can be criticized for giving a somewhat oversimplified picture of the phenomenon. However, the answers were rather polarized. This maybe due to the cross sectional data and the question that encouraged participants to reflect the relationship with their primary scholarly community. In the cases where students reported more mixed feelings about their scholarly community the answers were analyzed based on the most prominent features of the experience that they emphasized. Usually in case of mixed answers about the perceived agency, students reported that they wished to have different kind of role that they currently and they had a negative feeling due to this ambivalent experience. The method used also allowed comparing these answers to the open-ended 
questions with scales measuring well-being as well as some background variable that resulted in a deeper understanding of the students' experiences.

Statistical procedures were applied to complement the qualitative analysis and to study the relation between sense of agency, experienced well-being and study persistence. The differences in experienced well-being in terms of anxiety, exhaustion and lack of interest between students who experienced themselves as active subject and those who experienced themselves as passive objects were measured with an independent samples t-test (significance level $\mathrm{p}$ $\leq .05$ ). The effect sizes were calculated using Cohen's d, where $<0.3$ equals a small effect, $>0.50$ equals a medium effect, and $>0.8$ equals a large effect. The relations between sense of agency and intentions to interrupt studies, the discipline in question and research group status as well as phase of the studies were measured with cross-tabulations and $\chi^{2}$-tests (significance level $\mathrm{p} \leq .05$ ).

\section{Results}

\subsection{Students' sense of relational agency}

The results showed that the doctoral students' perceptions of both the scholarly community and of themselves as members of it varied considerably. Some students' descriptions reflected a perception of themselves as important members of the scholarly community, and more specifically, as active, valued agents whose ideas and contributions mattered. On the other hand, a number of students also viewed themselves as outsiders, feeling that they had no role in the community. These students often felt that their actions were primarily influenced by external factors. Some described their role in the community as insignificant, and sometimes considered themselves to be mere commodities for the community. Thus the students' descriptions of themselves in the scholarly community varied in terms of how active vs. passive they saw themselves.

About one third (30\%) of the students described themselves as active subjects in their scholarly community. They viewed themselves as members of a scholarly community in which their actions mattered. They felt that their engagement with the community promoted their sense of contribution and belonging during the PhD process. The relationship between themselves and the community was considered to be reciprocal. The students described both receiving support (e.g. feedback or advice) from the community as well as being able to contribute to its shared work and achievements. They also often reported being appreciated by other members of the community, this applying to their work as well.

"Sometimes I consider myself still as a student when it comes to doing research and sometimes I already perceive to be an expert in my area. I feel that I'm doing a meaningful and important work in my scholarly community."

In addition, the supervisor's role in promoting student engagement with the community was often emphasized. This was reflected for instance in students' descriptions of how their supervisors helped them participate in the community and how supervisors made it easier for students to meet others in the same field. In general, students who described themselves as subjects reported their work to be important within in their own group and discipline. Accordingly, these students perceived the scholarly community as a source of inspiration and empowerment in terms of their own learning in the doctoral process.

The students reported different ways of actively participating in the activities of their scholarly community. These arenas of participation varied a great deal in the students' descriptions. Some students described their participation as working in research groups and interacting with their colleagues, both peers and faculty. Others emphasized participating in the scholarly community in terms of attending scientific meetings and conferences, presenting their own research and discussing it with other academics. Contributing to the literature was also considered a way of being a member of the academic community, as expressed below:

"I contribute to the research made in the same field. This makes my own work more meaningful and that's why it is important to have collaboration among researchers!"

"I see myself as part of the international scholarly community in my own field. I feel that I can contribute to it, because my thesis represents a point of view that clearly differs from others."

"I believe that my work will open certain aspects in our field for further investigation and that it provides new information. As a $\mathrm{PhD}$ student I'm an independent researcher and equal to others, but on the other hand I'm a student, who has the right to not know everything and to ask and receive answers and guidance." 
Further analysis showed that the majority of students (70\%) perceived themselves as passive objects in their scholarly community. These students reported experiences of being an outsider or not being able to contribute anything meaningful. They sometimes reported a sense of being important from the perspective of benefits to the department. These students often stated that their relationship with the community was negative, and often considered the scholarly community to be an exhausting burden in the $\mathrm{PhD}$ process. Such responses reflected experiences of not understanding what the scholarly community was and/or experiences of simply not seeing oneself as part of that community. Many students explicitly reported that they missed having a connection to the scholarly community and to other researchers in the same field, and explained that this kind of relationship with the academic community would benefit them and make the thesis process easier.

"[I see myself as] Accepted, diligent writer, who holds a lot of potential - as a 'product' that needs to answer to requirements."

"[I see myself as] Important, because departments need to produce $\mathrm{PhDs}$ in order to get funding and improve their status."

"Is there anything special to see in it? Basically you're just a hindrance to others. What role can you adopt for yourself, if you're nothing but at the mercy of others. You'll just do your job alone without any help from the others. You'd better not criticize the system, because that will have bad consequences!"

\subsection{Relations between sense of relational agency, well-being, study phase and study persistence}

The results further suggested that sense of relational agency was related to experienced socio-psychological well-being during the $\mathrm{PhD}$ process. Students who viewed themselves as active agents also reported experiencing less negative emotions than those who described themselves as passive objects. The perceived relational agency was not, however, related to the phase of doctoral studies. As Table 3 shows, students who perceived themselves as active relational agents in their scholarly communities suffered less from exhaustion and anxiety, and experienced greater interest towards their own work than the others.

Insert Table 3 here

Moreover, students who saw themselves as active agents had considered interrupting their studies less often than those who saw themselves as objects in terms of their scholarly community (Table 4).

Insert Table 4 here

\subsection{Sense of relational agency, discipline, and research group status}

Results showed no relation between sense of agency and the discipline in question. This indicates that most students in each discipline considered themselves as objects rather than subjects in their communities. Further analysis, however, revealed a statistically significant relation between sense of relational agency and research group status. Table 5 shows that students working in research groups considered themselves to be active agents in the scholarly community more often than students who reported working mainly on their own.

Insert Table 5 here

\section{Discussion}

\subsection{Methodological reflections}

In the present study, survey data was collected to capture doctoral students' perceptions of their relational agency in the disciplines of medicine, behavioural science and the humanities. The cross- sectional survey data gave us an opportunity to explore perceived agency among a large number of doctoral students from different domains. The reflective and open-ended research design also gave the doctoral students an opportunity to reflect on various aspects of their participation in scholarly communities and hence allowed us to study their sense of relational agency. Our findings showed that there were no relationship between perceived agency and study phase. This suggests that students do not necessarily become more agentic in terms of their communities while they studies progress. However, further research, particularly longitudinal and qualitative designs, are needed in order to examine the development of relational agency across an extended period of time.

The study's response rate was moderate. However, the representativeness of the sample was sufficient. Previous studies (Krosnick, 1999; Cook, Heath \& Thompson, 2000) have shown that sample representativeness is a much more important criterion for evaluating the validity of a study than response rate. One reason for our moderate response rate that was counted based on doctoral student registers is likely to be the Finnish doctoral education system itself: it allows students to be enrolled for life even though in practice one may have abandoned doctoral 
studies entirely. Our survey was, however, addressed to those doctoral student who were currently conducting their doctoral studies, hence the active doctoral students are likely to be over presented in our data.

The survey data was collected from 669 doctoral students from a large research- intensive Finnish university. Due to the distinctive features of Finnish doctoral education and domains (Becher 1994; McCune \& Hounsell, 2005; Lindblom-Ylänne, Trigwell, Nevgi \& Ashwin, 2006) one must be cautious not to apply the results to other domains and other countries. Still, the open-ended answers provided rich data with which to identify and analyse doctoral students' sense of relational agency in their scholarly communities. Hence these findings are also relevant to further studies in the area of doctoral student agency. However, further qualitative and longitudinal studies are needed to develop more profound understanding on different aspects and development of doctoral student's agency in their scholarly communities.

\subsection{The results in light of previous research}

Our results suggested that doctoral students' active participation in their scholarly communities cannot be taken for granted. The majority of participants did not perceive themselves as active relational agents in terms of their own community. The prior research shows that scholarly community plays a central role in student attrition: a students who enters a department whose culture and practices facilitate academic and personal integration is more likely to complete the Ph.D. than a student whose departmental culture is hostile or laissez-faire (Lovitts \& Nelson, 2000). Hence, a lack of relational agency in terms of the student's scholarly community may contribute to doctoral student attrition. However, a lack of relational agency in a particular context does not mean that doctoral students cannot experience themselves as active agents in other aspects of their work. Nor does it mean that active relational agency, in terms of scholarly community, cannot be developed (Greeno, 2006). It does imply, however, that a doctoral student's active relational agency with respect to the scholarly community, although always shaped by the student's prior experiences, is also constantly negotiated and re-constructed in the social practices of the community, and thus must be facilitated in these working environments.

Our study also showed that a sense of active relational agency was related to lower levels of exhaustion and anxiety. Moreover, doctoral students who perceived themselves as active relational agents in their scholarly community experienced less lack of interest in their studies and had less often considered interrupting their studies. The findings indicate that active participation in the scholarly community reduces disengagement, negative emotions and risk of dropping out, and is hence likely to promote student satisfaction with studies. This is in line with literature suggesting that active involvement in the scholarly community contributes to resilience when facing problems (Golde, 2005; Lovitts, 2008; Stubb et al, 2011).

Quite surprisingly, despite disciplinary differences in organizing doctoral education no statistically significant differences were noted concerning students' sense of relational agency between the faculties. This contradicts the findings of previous studies suggesting that disciplinary practices are the central determinant in the doctoral experience (Becher \& Trowler 2001). Our findings indicate that one should be cautious not to draw extensive, oversimplifying conclusions based solely on disciplinary differences since already the variation within one domain may be great, and the discipline (e.g. Brew, 2001; Kamler, 2008) is only one influencing factor within the complexity of elements that contribute to doctoral student relational agency. However, the doctoral student's sense of relational agency was related to research group status: students who carried out their thesis work as part of a research group perceived themselves more often as active relational agents. This suggests that although working in a research group does not guarantee meaningful and reciprocal involvement in the practices of the group, a sense of active relational agency more frequently occurred in group-based settings. This indicates that, at its best, collaborative practices of the social community can provide ground for promoting doctoral student's relational agency.

To become an active relational agent in terms of scholarly community, a doctoral student must be treated as one. In other words, to develop sufficient competence to participate, manage, and support one another's active relational agency by producing new knowledge, students must experience these situations themselves . Accordingly, one could argue that if a doctoral student has had an opportunity to develop skills and a participatory professional identity as well as to construct an integrated understanding of aims and means with respect to creating knowledge (Zerbe, 1993) with an overall understanding of the environment (Battista, 1994) during the development process, she or he is more likely to generate, implement, scale up, and actively modify new ideas and research innovations. Thus a central challenge for scholarly communities and supervisors is to find ways to utilize doctoral students' potential as the future of the community. This includes creating arenas in which doctoral students are seen as expert contributors whose ideas, input and suggestions are recognized and acknowledged. The development of agency during the 
doctoral process serves as grounds for future development of academic identity and agency during the next stages of the academic careers (e.g. Southerland \& Taylor, 2011; Mathieson, 2011).

\section{Acknowledgements}

This study was supported by grants from Helsinki University (2106008).

\section{References}

Anderson, B. (2011). Predictive relationships among learner characteristics, academic involvement, and doctoral education outcomes. Dissertation Prepared for the Degree of Doctor of Philosophy. Department of Counseling and Higher Education, University of North Texas, United Stated of America.

Anderson, S., \& Anderson, B. (in press). Preparation and socialization of the education professoriate: Narratives of doctoral student-instructors. International Journal of Teaching and Learning in Higher Education.

Anderson, M., Louis, K., \& Earle, J. (1994). Disciplinary and departmental effects on observations of faculty and graduate student misconduct. Journal of Higher Education, 65, 331-350. [Online] Available: http://www.jstor.org/stable/2943971

Appel, M., \& Dahlgren, L. (2003). Swedish doctoral students' experiences on their journey towards a PhD: obstacles and opportunities inside and outside the academic building. Scandinavian Journal of Educational Research, 47(1), 89-110. http://dx.doi.org/10.1080/00313830308608

Austin, A. E. (2002). Preparing the next generation of faculty: Graduate school as socialization to the academic career. The Journal of Higher Education, 73, 94-122. http://dx.doi.org/10.1353/jhe.2002.0001

Barnes, B. J., \& Randall, J. (in press). Doctoral student satisfaction: An examination of disciplinary, enrollment, and institutional differences. Research in Higher Education. [Online] Available: http://www.springerlink.com/content/g238711414224452/

Battista, M. T. (1994). On Greeno's environmental/model view of conceptual domains: A spatial/geometric perspective. Journal for Research in Mathematics Education, 25, 86-93. [Online] Available: http://www.jstor.org/stable/749293

Becher, T. (1994). The significance of disciplinary differences. Studies in Higher Education 19(2), 151-161. http://dx.doi.org/10.1080/03075079412331382007

Becher, T., \& Trowler, P. (2001). Academic tribes and territories: Intellectual enquiry and the culture of disciplines. Philadelphia, PA: Open University Press.

Brew, A. (2001). Conceptions of research: a phenomenographic study. Studies in Higher Education, 26(3), 271-285. http://dx.doi.org/10.1080/03075070120076255

Bauer, M., Abric, J. C., Drozda-Senkowska, E., Lemaire, P., Lorenzi-Cioldi, F, Niedenthal, P., Santioso, R. B., Schadron, G., Steiner, D., \& Yzerbyt, V. (2003). Doctoral training in the French-speaking countries of Europe: objectives and suggestions for improvement. European Psychologist, 8, 9-17. http://dx.doi.org/10.1027//1016-9040.8.1.9

Coffey, A., \& Atkinson, P. (1996). Making sense of qualitative data. Complementary research strategies. Thousand Oaks, CA: Sage.

Cook, C.,Heath, F. \& Thompson, R. (2000). A Meta-Analysis of Response Rates in Web- or Internet-Based Surveys. Educational and Psychological Measurement, 60 (6), 821-836. http://dx.doi.org/10.1177/00131640021970934

Cook, M. M., \& Swanson, A. (1978). The interaction of student and program variables for the purpose of developing a model for predicting graduation from graduate programs over a 10-year period. Research in Higher Education, 8(1), 83-91. http://dx.doi.org/10.1007/BF00985858

Deci, E.L. \& Ryan, R.M. (2002). "An overview of Self-Determination Theory: An organismic-dialectical perspective". In E.L. Deci, \& R. M. Ryan (Eds.), Handbook of self-determination research (pp. 3-33). Rochester: The University of Rochester Press.

Delamont, S., \& Atkinson, P. (2001). Doctoring Uncertainty: Mastering craft knowledge. Social Studies of Science, 31(1), 87-107. http://dx.doi.org/10.1177/030631201031001005 
Dysthe, O. Samara A. \& Westrheim, K. (2006). Multivoiced supervision of Master's students: a case study of alternative supervision practices in higher education. Studies in Higher Education, 31, $299-318$. http://dx.doi.org/10.1080/03075070600680562

Eccles, J. (2008). Agency and structure in human development. Research in human development, 5, $231-243$. http://dx.doi.org/10.1080/15427600802493973

Edwards, A. (2005). Relational agency: Learning to be a resourceful practitioner. International journal of educational research, 43, 168-182. http://dx.doi.org/10.1016/j.ijer.2006.06.010

Edwards, A. (2007). Relational agency in professional practice: A CHAT analysis. Actio: An international journal of human activity theory, 1, 1-17. [Online] Available: http://www.tlrp.org/dspace/handle/123456789/1043

Edwards, A., Lunt, I. \& Stamou, E. (2010). Inter-professional Work and Expertise: new roles at the boundaries of schools, British Educational Research Journal, 36(1), 27-45. http://dx.doi.org/10.1080/01411920902834134

Edwards, A. (2011). Building Common Knowledge at Boundaries between Professional Practices, International Journal of Educational Research, 50 (1), 33-39. http://dx.doi.org/10.1016/j.ijer.2011.04.007

Ehrenberg, R. G., Jakubson, G. H., Groen, J. A., So, E., \& Price, J. (2007 ). Inside the black box of doctoral education: What program characteristics influence doctoral students' attrition and graduation probabilities? Educational Evaluation and Policy Analysis, 29(2), 134-150. http://dx.doi.org/10.3102/0162373707301707

Elder, G. H. (1997). The life course and human development. In W. Damon and R. M: Lerner (Eds.), Handbook of child psychology (5 $5^{\text {th }}$ ed. pp.-939-991). New York, NY: Wiley

Elo, A-L., Leppänen, A., \& Jahkola, A. (2003). Validity of single-item measure of stress symptoms. Scandinavian Journal of Work, Environment and Health, 29(6), 444-604. http://dx.doi.org/10.5271/sjweh.752

Gardner, S. K. (2007). "I heard it through the grapevine": Doctoral student socialisation in chemistry and history. Higher Education, 54(5), 723-740. http://dx.doi.org/10.1007/s10734-006-9020-x

Gardner, S. K. (2008). Fitting the mold of graduate school: A qualitative study of socialization in doctoral education. Innovations in Higher Education, 33, 125-138. http://dx.doi.org/10.1007/s10755-008-9068-x

Gardner, S. K. (2010). Doctoral student development. In S. K. Gardner, \& P. Mendoza (Eds.), On becoming a scholar. Socialization and development in doctoral education (pp. 203-223). Virginia, USA: Stylus Publishing, LLC.

Golde, C. (2000). Should I stay or should I go? Student descriptions of the doctoral attrition process. The Review of Higher Education, 23(2), 199-227. http://dx.doi.org/10.1353/rhe.2000.0004

Golde, C. (2005). The role of the department and discipline in doctoral student attrition: Lessons from four departments. The Journal of Higher Education, 76(6), 669-700. [Online] Available: http://www.jstor.org/stable/3838782

Golde, C. M., Bueschell, A.C., Jones, L., \& Walker, G.E. (2009). Advocating apprenticeship and intellectual community: Lessons from the Carnegie Initiative on the Doctorate. In R. G. Ehrenberg, \& C. V. Kuh (Eds.), Doctoral education and the faculty of the future (pp. 53-64). Ithaca, NY: Cornell University Press.

Greeno, J. G. (2006). Authoritative, accountable positioning and connected, general knowing: Progressive themes in understanding transfer. The Journal of learning sciences, 15, 537-547. http://dx.doi.org/10.1207/s15327809j1s1504_4

Haworth, J. G., \& Bair, C. R. (2000). Learning experiences that make a difference: Findings from a national study of doctoral education in the professions. Paper session presented at a meeting of the Association for the Study of Higher Education, Sacramento: CA.

Holley, K. (2010). Doctoral student socialization in interdisciplinary fields. In S. K. Gardner, \& P. Mendoza (Eds.), On becoming a scholar. Socialization and development in doctoral education (pp.97-112). Virginia, USA: Stylus Publishing, LLC.

Hopwood, N. (2010). A sociocultural view of doctoral students' relationships and agency. Studies in Continuing Education, 32(2), 103-117. http://dx.doi.org/10.1080/0158027X.2010.487482

Kamler, B. (2008). Rethinking doctoral publication practices: Writing from and beyond the thesis. Studies in Higher Education, 33(3), 283-294. http://dx.doi.org/10.1080/13562510802334723 
Kristof, A.L. (1996). Person-organization fit: An integrative review of its conceptualizations, measurement, and implications. Personnel Psychology 49(1), 1-49. http://dx.doi.org/10.1111/j.1744-6570.1996.tb01790.x

Krosnick, J. (1999). Survey research. Annual Review of Psychology, 50, 537-567. [Online] Available: http://www.annualreviews.org/doi/pdf/10.1146/annurev.psych.50.1.537

Lipponen, L., \& Kumpulainen, K. (2011). Acting as accountable authors: Creating interactional spaces for agency work in teacher education. Teaching and teacher education, 27, 812-819. http://dx.doi.org/10.1016/j.tate.2011.01.001

Lindblom-Ylänne, S., Trigwell, K., Nevgi, A., \& P. Ashwin (2006). How approaches to teaching are affected by discipline and teaching context. Studies in Higher Education, 31(3), 285-298. http://dx.doi.org/10.1080/03075070600680539

Lonka, K., Sharafi, P., Karlgren, K., Masiello I., Nieminen, J., Birgegård, G., \& Josephson, A. (2008). Development of MED NORD - a tool for measuring medical students' well-being and study orientations. Medical Teacher, 30(1), 72-79. [Online] Available: http://www.ncbi.nlm.nih.gov/pubmed/18278655

Lovitts, B. E. \& Nelson, C. (2000). The Hidden Crisis in Graduate Education: Attrition From Ph.D. Programs. The source of graduate student attrition is not inadequate students but indifferent and wasteful programs. AcademiOnline. 86 (6). [Online] Available: http://www.aaup.org/AAUP/pubsres/academe/2000/ND/Feat/lovi.htm

Lovitts, B. E. (2001). Leaving the ivory tower. The causes and consequences of departure from doctoral study. New York: Roman and Littlefield.

Lovitts, B. E. (2005). Being a good course-taker is not enough: A theoretical perspective on the transition to independent research. Studies in Higher Education, 30(2), 137-154. [Online] Available: http://www.jstor.org/stable/10.2307/25144670

Lovitts, B. E. (2008). The transitions to Independent Research: Who Makes It, Who Doesn't, and Why. The Journal of Higher Education, 79 (3), 296-325. [Online] Available: http:www.jstor.org/stable/25144670

Maslach, C., \& Jackson, S.E. (1981). The measurement of experienced burnout. Journal of Occupational Behavior, 2(2), 99-113. http://dx.doi.org/10.1002/job.4030020205

Mathieson, S. (2011). Developing academic agency through critical reflection: A sociocultural approach to academic induction programmes. International Journal for Academic Development, 16(3), 243-256. http://dx.doi.org/10.1080/1360144X.2011.596730

McAlpine, L., \& Norton, J. (2006). Reframing our approach to doctoral programs: an integrative framework for action and research. Higher Education Research \& Development, 25(1), 3-17. http://dx.doi.org/10.1080/07294360500453012

McCune, V., \& D. Hounsell (2005). The development of students' way of thinking and practising in three final-year biology courses. Higher Education, 49, 255-289. http://dx.doi.org/10.1007/s10734-004-6666-0

Mäkinen, J., Olkinuora, E., \& Lonka, K. (2004). Students at risk: General study orientation and abandoning/prolonging the course of studies. Higher Education, 48(2), 173-188. http://dx.doi.org/10.1023/B:HIGH.0000034312.79289.ab

Nettles, M. T., \& Millet, C. M. (2006). Three magic letters: Getting to Ph.D. Baltimore: The John Hopkins University Press.

Neumann, A., Terosky, A.L. \& Schell, J. (2006). Agents of learning: Strategies for assuming agency, for learning, in tenured faculty careers. In S. Bracken, J. Allen, \& D. Dean (Eds.), The balancing act: Gendered perspective in faculty roles and work lives (pp. 91-120). Sterling, VA: Stylus.

O’ Meara, K., Terosky, A.L. \& Neumann, A. (2008). Faculty careers and work lives: A professional growth perspective. ASHE Higher Education Report, 34 (3). San Fransisco, CA: Jossey-Bass.

O’ Meara, K, \& Campbell, C. M. (2011). Faculty sense of Agency in Decisions about Work and Family. The Review of Higher Education, 34 (3), 447-476. http://dx.doi.org/10.1353/rhe.2011.0000

Pyhältö, K, Stubb, J. \& Lonka, K. (2009). Developing a scholarly community as a learning environment for Ph.D. students. International Journal for Academic Development, 14, (3), 221-232. http://dx.doi.org/10.1080/13601440903106551 
Pyhältö, K., Pietarinen, J., \& Soini, T. (2011). Do Comprehensive School Teachers Perceive Themselves as Active Professional Agents in School Reforms? Journal of Educational Change, 13(1), 95-116. http://dx.doi.org/10.1108/09578231111102054

Pyhältö, K., Stubb, J. \& Tuomainen, J. (2011). International evaluation of research and doctoral education at the University of Helsinki. To the top and out to society. Summary report on doctoral students' and principal investigators doctoral training [Online] Available: http://wiki.helsinki.fi/display/evaluation2011/Survey+on+doctoral+training

Pyhältö, K., Nummenmaa, A-R, Stubb, J. \& Soini, T., Lonka, K. (2012). Research on scholarly communities and development of scholarly identity in Finnish doctoral education. S. Ahola \& D. Hoffman (eds.) Consortium of Higher Education Researchers in Finland. (pp. 337-354) Yearbook of Higher Education Research.

Pyhältö, K., Pietarinen, J., \& Soini, T. (2012). (submitted). Teaching and Teacher Education. Comprehensive School Teachers' Professional Agency in Large-Scale Educational Innovation. Teaching and Teacher Education..

Pyhältö, K., Toom, A. Stubb, J. \& Lonka, K. (2012). Challenges of becoming a scholar: A study of experienced problems and well-being of doctoral students. ISRN Education. [Online] Available: http://www.isrn.com/journals/education/aip/934941/

Pyhältö, K., Tuomainen, J. \& Stubb, J. (2012). (submitted). Exploring the Fit between Doctoral Student's and Supervisor's Perceptions about the Resources and Challenges in the Doctoral Journey. International Journal of Doctoral Studies.

Sainio, J. (2010). Asiantuntijana työmarkkinoille - Vuosina 2006 ja 2007 tohtorin tutkinnon suorittaneiden työllistyminen ja heidän mielipiteistään tohtorikoulutuksesta. Kirjapaino Hermes Oy.

Scaffidi, A. K., \& Bergnman, J. E. (2011). A positive postdoctoral experience is related to quality supervision and career mentoring, collaboration, networking and a nurturing research environment. Higher Education, 62(6), 685-698. http://dx.doi.org/10.1007/s10734-011-9407-1

Stubb, J., Pyhältö, K. \& Lonka, K. (2010). Balancing between Inspiration and Exhaustion? Ph.D. Students' Experienced. Studies in Continuing Education, 14, (3), 221-232. http://dx.doi.org/10.1080/0158037X.2010.515572

Sutherland, K., \& Taylor, L. (2011). The development of identity, agency and community in the early stages of the academic career. International Journal for Academic Development, 16(3), 183-186. http://dx.doi.org/10.1080/1360144X.2011.596698

Swedish National Agency for Higher Education. (2006). International postgraduate students mirror. Catalonia, Finland, Ireland and Sweden (Report 2006:29 R). Stockholm: Swedish National Agency for Higher Education.

Toews, J. A., J.M. Lockyer, D. J. Dobson, \& A. K. Brownell. (1993). Stress among residents, medical students and graduate science $(\mathrm{MSc} / \mathrm{PhD})$ students. Academic Medicine, 68, 46-8. http://dx.doi.org/10.1097/00001888-199310000-00042

Truong, K. (2010). Racism and racial trauma in doctoral study: How students of colour experience and negotiate the political complexities of racist encounters. A Doctoral Dissertation in Education. University of Pennsylvania. United States of America.

Virtanen, V., \& Pyhältö, K. (2012). (submitted). What Engages Doctoral Candidates in Biological and Environmental Science to Doctoral Studies? Science Education.

Walker, J. (2010). Measuring plagiarism: Researching what students do, not what they say they do. Studies in Higher Education, 35, 41-59. http://dx.doi.org/10.1080/03075070902912994

Weidman, J. C., \& E.L. Stein. (2003). Socialization of graduate students to academic norms. Research in Higher Education, 44, 641-656. http://dx.doi.org/10.1023/A:1026123508335

Wenger, E. (1998). Communities of practice: Learning, meaning, and identity. New York: Cambridge University Press.

Wulff, D. H., \& Nerad, M. (2006). Using an alignment model as a framework in the assessment of doctoral edication. In P. Maki, \& N. A. Borkowski (Eds.). The assessment of doctoral education: Emerging criteria and new models for improving outcomes. Sterling, VA: Stylus.

Zerbe, C. (1993). Integrating separate and connected knowing: The experiential learning model. Teaching and psychology, 20,7-13. http://dx.doi.org/10.1207/s15328023top2001_2 
Table 1. Statistics (year 2008) for gender distribution and mean age in different disciplines at the University of Helsinki according to Statistics Finland and the university's own statistics compared to the sample of this study

\begin{tabular}{lccc}
\hline & Women & Men & Age (mean) \\
\hline Humanities & $66 \%$ & $34 \%$ & 42.4 \\
In our sample & $71 \%$ & $29 \%$ & 38 \\
& & & 53.1 \\
Behavioural sciences & $76 \%$ & $24 \%$ & 41 \\
In our sample & $79 \%$ & $21 \%$ & 35.3 \\
& & & 38 \\
Medicine & $71 \%$ & $29 \%$ & \\
In our sample & $80 \%$ & $20 \%$ & \\
& & & \\
\hline
\end{tabular}

Table 2. The modified MED NORD (Lonka et al. 2008) Items included in the Questionnaire

\begin{tabular}{|c|c|c|}
\hline Scale & Items included on the scale & Cronbach's Alpfa $\alpha$ \\
\hline \multirow[t]{2}{*}{$\begin{array}{l}\text { Stress } \\
\text { (Based on Elo et al., 2003) }\end{array}$} & $\begin{array}{l}\text { Stress means a situation in which a person feels } \\
\text { tense, restless, nervous or anxious, or is unable to } \\
\text { sleep because he/she is always troubled. }\end{array}$ & \\
\hline & "Do you feel this kind of stress these days?" & \\
\hline \multirow{4}{*}{$\begin{array}{l}\text { Exhaustion } \\
\text { (Based on Maslach \& Jackson, 1981) }\end{array}$} & "I feel exhausted" & .821 \\
\hline & "My workload is often too high" & \\
\hline & "Doctoral studies are too stressful for me" & \\
\hline & "I worry about the thesis in my free time" & \\
\hline \multirow{3}{*}{$\begin{array}{l}\text { Anxiety } \\
\text { (Based on Mäkinen et al., } \\
\text { 2004) }\end{array}$} & $\begin{array}{l}\text { "I often fear that I will fail in my doctoral } \\
\text { studies" }\end{array}$ & .653 \\
\hline & $\begin{array}{l}\text { "I am stressed by the workload, deadlines and } \\
\text { competition in doctoral studies" }\end{array}$ & \\
\hline & $\begin{array}{l}\text { "I often have to force myself to work on my } \\
\text { thesis" }\end{array}$ & \\
\hline \multirow[t]{2}{*}{$\begin{array}{l}\text { Lack of interest } \\
\text { (Based on Mäkinen et al., 2004) }\end{array}$} & $\begin{array}{l}\text { "It is difficult for me to find meaning in my } \\
\text { doctoral studies" }\end{array}$ & .758 \\
\hline & $\begin{array}{l}\text { "I am not motivated by the content of my } \\
\text { studies" }\end{array}$ & \\
\hline
\end{tabular}

Note. All scales ranged from one to five: " 1 " meaning "Do not agree" and " 5 " meaning "Fully agree". On the single item stress scale "1" meant "Not at all" and "5" meant "Very much". 
Table 3. Sense of relational agency in relation to negative emotions

\begin{tabular}{lllll}
\hline & $\begin{array}{l}\text { Subject } \\
\text { mean (SD) }\end{array}$ & $\begin{array}{l}\text { Object } \\
\text { mean (SD) }\end{array}$ & $\mathrm{t}(\mathrm{df})$ & $\mathrm{p}$ \\
Exhaustion & $2.63(.91)$ & $2.82(.95)$ & $\mathrm{t}=-1.932(477)$ & .050 \\
Anxiety & $2.62(.87)$ & $2.81(1.0)$ & $\mathrm{t}=-2.044(273.005)$ & .042 \\
Lack of interest & $1.92(.93)$ & $2.25(1.1)$ & $\mathrm{t}=-3.312(284.392)$ & .001 \\
\hline
\end{tabular}

Table 4. Sense of relational agency in relation to intentions to interrupt studies

\begin{tabular}{llll}
\hline & $\begin{array}{l}\text { Has considered } \\
\text { interrupting studies }\end{array}$ & $\begin{array}{l}\text { Has_not considered } \\
\text { interrupting studies }\end{array}$ & Total \\
\hline Subject & 50 & 83 & 133 \\
& $38 \%$ & $62 \%$ & $100 \%$ \\
Object & 169 & 175 & 344 \\
& $49 \%$ & $51 \%$ & $100 \%$ \\
Total & 219 & 258 & 477 \\
& $46 \%$ & $54 \%$ & $100 \%$ \\
\hline
\end{tabular}

Note. $\chi^{2}=5.14, \mathrm{df}=1$, sig. $=.023$

Table 5. Sense of relational agency and research group status

\begin{tabular}{lllll}
\hline & Alone & In a group & Both & Total \\
\hline Subject & 89 & 23 & 17 & 129 \\
& $69 \%$ & $18 \%$ & $13 \%$ & $100 \%$ \\
Object & 264 & 43 & 24 & 331 \\
& $80 \%$ & $13 \%$ & $7 \%$ & $100 \%$ \\
Total & 353 & 66 & 41 & 460 \\
& $77 \%$ & $14 \%$ & $9 \%$ & $100 \%$ \\
\hline
\end{tabular}

Note. $\chi^{2}=6.576, \mathrm{df}=2$, sig. $=.037$ 